\title{
PENERAPAN MODEL PEMBELAJARAN PADU PADAN UNTUK MENINGKATKAN KEAKTIFAN DAN HASIL BELAJAR SISWA PADA MATA PELAJARAN BAHAN BANGUNAN KELAS X TEKNIK GAMBAR BANGUNAN SMK X TAHUN AJARAN 2015/2016. Silviana Putri Nurllinda Sari ${ }^{1}$, Anis Rahmawati ${ }^{2}$, Aryanti Nurhidayati ${ }^{3}$
}

\begin{abstract}
ABSTRAK
Tujuan penelitian ini adalah untuk mengetahui peningkatan keaktifan belajar siswa dan untuk mengetahui hasil belajar bahan bangunan setelah dilakukan penerapan pembelajaran dengan padu padan model pembelajaran Student Team Achievement Division (STAD), Think Pair Share (TPS), dan Problem Based Learning (PBL) pada siswa kelas X TGB SMK X tahun ajaran 2015/2016.

Penelitian ini merupakan penelitian tindakan kelas, penelitian ini dilaksanakan dalam 2 siklus. Sumber data berasal dari pendidik dan peserta didik. Teknik pengumpulan data dengan metode wawancara, observasi, dokumentasi dan tes peserta didik.

Hasil penelitian disimpulkan bahwa, (1) penggunaan model pembelajaran padu padan dapat meningkatkan keaktifan siswa dalam pembelajaran yang awalnya pada pra siklus siswa hanya ramai dengan teman sebangkunya, perlahan siswa memperhatikan guru dalam menjelaskan materi, siswa lebih berani dalam mengemukakan pendapatnya dalam pembelajaran dan diskusi kelompok. (2) penggunaan model pembelajaran padu padan dapat meningkatkan hasil belajar siswa pada ranah kognitif, persentase ketuntasan pra siklus $21,8 \%$, pada siklus I $62,5 \%$, sedangkan pada siklus II meningkat menjadi 82,3\%, (3) Ranah afektif pada pra siklus, siswa yang mendapat predikat baik (B) sebanyak 8 siswa pada siklus I meningkat menjadi 16 siswa, pada siklus II mengalami peningkatan 21 siswa dan 9 siswa berpredikat sangat baik (SB), (4) Ranah Psikomotorik juga mengalami peningkatan yaitu pada pra siklus persentase ketuntasan siswa sebesar 37,5\% pada siklus I sebesar $62,8 \%$ dan pada siklus II menjadi $88,2 \%$.
\end{abstract}

Kata Kunci : Model Pembelajaran Padu Padan

\footnotetext{
${ }^{1}$ Mahasiswa Program Studi Pendidikan Teknik Bangunan FKIP UNS

${ }^{2}$ Pembimbing I Anis Rahmawati, S.T., M.T

${ }^{3}$ Pembimbing II Aryanti Nurhidayati, S.T., M.Eng
} 


\title{
MIX AND MATCH LEARNING MODEL APPLICATION TO IMPROVE STUDENT LEARNING AND RESULTS LIVELINESS SUBJECT TO BUILDING MATERIALS BUILDING DRAWING TECHNIQUES CLASS X X SMK 2015/2016 ACADEMIC YEAR. Silviana Putri Nurllinda Sari ${ }^{1}$, Anis Rahmawati ${ }^{2}$, Aryanti Nurhidayati ${ }^{3}$
}

\begin{abstract}
The purpose of this study was to determine the increase in students' learning activeness and to know the results of study of building materials after the application of learning to mix and match the learning model Student Team Achievement Division (STAD), Think Pair Share (TPS), and Problem Based Learning (PBL) on students TGB X class X SMK academic year 2015/2016.

This research was a class action, the research was conducted in two cycles. Source of data derived from educators and learners. Techniques of collecting data by interview, observation, documentation and testing of learners.

The results of the study concluded that, (1) the use of the learning model mix and match can enhance the activity of students in the beginning in pre-cycle students only crowded with friends sebangkunya, slowly the students pay attention to the teacher in explaining the material, students are more daring in expressing his opinions in learning and group discussion , (2) the use of a solid match learning model can improve student learning outcomes in the cognitive domain, completeness percentage $21.8 \%$ pre-cycle, the first cycle of $62.5 \%$, while in the second cycle increased to $82.3 \%$, (3) The sphere of affective on pre-cycle, students who received a good rating (B) as many as eight students in the first cycle increased to 16 students, on the second cycle increased 21 students and 9 students predicated excellent (SB), (4) the sphere Psychomotor also increased, namely on pre-cycle the percentage of completeness of students by $37.5 \%$ in the first cycle of $62.8 \%$ and in the second cycle to $88.2 \%$.
\end{abstract}

Keywords: Matching Learning Model

\footnotetext{
${ }^{1}$ Mahasiswa Program Studi Pendidikan Teknik Bangunan FKIP UNS

${ }^{2}$ Pembimbing I Anis Rahmawati, S.T., M.T.

${ }^{3}$ Pembimbing II Aryanti Nurhidayati, S.T., M.Eng.
} 


\section{PENDAHULUAN}

Pendidik merupakan salah satu sektor penting yang harus diperhatikan oleh suatu bangsa. Karena pada hakikatnya pendidik merupakan proses untuk membangun manusia dalam mengembangkan dirinya agar dapat menghadapi segala perubahan dan permasalahan yang terjadi dilingkungan sekitarnya. Pendidikan adalah usaha sadar dan terencana untuk mewujudkan pembelajaran, suasana belajar, dan proses belajar yang membantu peserta didik secara aktif mengembangkan potensi dirinya sendiri.

Guru merupakan tenaga pendidik yang secara langsung terlibat dalam proses belajar mengajar, maka guru sebagai pendidik memegang peranan penting dalam meningkatkan kualitas sumber daya manusia. Guru sebagai ujung tombak peningkatan mutu pendidikan, pengajar maupun pendidik sehingga guru dituntut untuk memiliki berbagai kompetensi yang diperlukan agar materi yang disampaikan dapat diterima dengan baik. Model pembelajaran yang digunakan guru sangat berpengaruh dalam menciptakan situasi belajar yang benar-benar menyenangkan dan mendukung kelancaran proses belajar mengajar, serta sangat membantu dalam pencapaian hasil belajar.

Oleh sebab itu guru senantiasa berinovasi dalam kegiatan belajarmengajar, agar terwujud pembelajaran yang efektif. Kesuksesan guru dalam mengantarkan siswanya memahami ilmu, dipengaruhi oleh beberapa hal, salah satunya desain model pembelajaran. Desain model pembelajaran merupakan desain yang cukup berpengaruh dalam pembelajaran. Sebab model pembelajaran berdampak pada hasil belajar siswa bila model pembelajaran inovatif tidak monoton, dan menyenangkan, tentunya membuat keaktifan belajar siswa menjadi tinggi. Dengan keaktifan siswa yang tinggi pada akhirnya dapat meningkatkan hasil belajar. Begitu juga sebaliknya apabila model pembelajaran yang digunakan monoton, membosankan tentu membuat kurangnya keaktifan 
dan berdampak pada rendahnya hasil belajar.

Beragam permasalahan ditemui dalam proses pembelajaran di sekolah. Diantaranya adalah kurangnya keaktifan serta keberanian siswa pada proses pembelajaran. Data yang diperoleh hasil observasi pada mata pelajaran Bahan Bangunan ketuntasan siswa mencapai $31,50 \%$ siswa yang mendapat nilai sesuai ketuntasan KKM yang ditentukan. Permasalahan-permasalahan tersebut berdampak pada kurang maksimalnya hasil belajar.

Berdasarkan masalah yang ada, maka guru dan peneliti merasa perlu untuk mengadakan perbaikan terhadap strategi pembelajaran berkaitan dengan model pembelajaran yang digunakan oleh guru. Dalam hal ini peneliti dan guru sepakat untuk menerapkan model pembelajaran padu padan. Keunggulan dari model pembelajaran ini yaitu mudah diterapkan pada berbagai tingkat kemampuan berpikir, dan dalam setiap kesempatan, serta prosedur yang digunakan juga sederhana. Sehingga pembelajaran dimana siswa sebagai pusat pembelajaran, bukan guru sebagai pusat pembelajaran. Siswa dapat aktif dalam melaksanakan proses pembelajaran. Proses dalam pembelajaran Bahan Bangunan menggunakan padu padan model pembelajaran sehingga mampu melibatkan keaktifan siswa dalam pembelajaran dan mampu meningkatkan hasil belajarnya. Dengan memadukan beberapa model pembelajaran, dari beragam model yang tersedia yaitu peneliti memadukan model pembelajaran Student Team Achievement Division (STAD), Think Pair Share (TPS), dan Problem Based Learning (PBL).

ROGER, dkk.

mengatakan Pembelajaran kooperatif merupakan aktivitas pembelajaran kelompok yang diorganisir oleh satu perinsip bahwa pembelajaran harus didasarkan pada perubahan informasi secara sosial diantara kelompokkelompok pembelajar yang didalamnya setiap pembelajar bertanggung jawab atas pembelajarannya sendiri dan didorong 
untuk meningkatkan pembelajaran anggota-anggota yang lain). Berdasarkan pendapat diatas maka dapat disimpulkan bahwa model pembelajaran kooperatif adalah kegiatan belajar mengajar yang dilakukan secara kelompok dan mempunyai tanggung jawab masingmasing dalam proses pembelajarannya.

Model pembelajaran padu padan merupakan perpaduan antara beberapa model pembelajaran dibawah model pembelajaran kooperatif yang dipadukan dengan mengoptimalkan kelebihan sekaligus meminimalisir kekurangan dari masing-masing model untuk proses pembelajaran. Model padu padan disebut juga dengan istilah multi metode atau bahasa latinnya "Multi Methodes". Menurut Tony Antony dalam Husen (1997:144) multi methodes adalah sebuah istilah untuk menyederhanakan bentuk umum yang melingkupi metode serta teknik pembelajaran di kelas. Multi methodes adalah menggabungkan dari tiga metode pembelajaran yaitu pembelajaran mandiri, pemecahan masalah kolaboratif, dan penyajian (Heydon 2007).

Berdasarkan pendapat diatas dapat diambil kesimpulan model pembelajaran padu padan merupakan teknik pembelajaran di kelas yang menggabungkan beberapa metode yang meliputi pembelajaran mandiri, pemecahan masalah kolaboratif dan penyajian.

\section{METODE}

Data penelitian diperoleh dari hasil wawancara, tes, dokumentasi, dan observasi peserta didik yang berpedoman pada lembar pengamatan untuk aspek afektif, psikomotorik serta kognitif yang berupa hasil belajar peserta didik. Sumber data diperoleh dari peserta didik dan juga guru mata pelajaran.

Teknik pengumpulan data penelitian ini meliputi: observasi, wawancara, dokumentasi, serta tes peserta didik. Observasi adalah teknik yang dilakukan dengan cara mengamati dan melihat langsung kejadian yang terjadi. Dokumentasi 
adalah cara pengumpulan data yang didapat dari catatan ataupun arsip. Tes digunakan untuk mengukur kemampuan seberapa besar pemahaman peserta didik dalam memahami materi yang telah diberikan. Wawancara merupakan pertanyaan-pertanyaan yang diajukan secara verbal kepada orang-orang yang dianggap dapat memberikan informasi atau penjelasan hal-hal yang dianggap perlu (Denzin dalam Goetz dan LeCompte 1984). Mengenai teknik analisis data yang digunakan dalam penelitian ini adalah deskriptif kualitatif. Analisis deskriptif kualitatif dilakukan dengan analisis interaktif yang terdiri dari reduksi data, penyajian data, dan penarikan kesimpulan.

Indikator kinerja penelitian keaktifan siswa diukur dari keaktifan diskusi, keaktifan bertanya dan keaktifan berpendapat, dengan nilai yang ditargetkan yaitu B yang diamati selama proses pembelajaran. Penilaian dilakukan dengan menggunakan lembar observasi, dengan keterangan Keaktifan Siswa (KS) sebagai berikut:
KS 4 keaktifan siswa sangat baik, KS 3 keaktifan siswa baik, KS 2 keaktifan siswa cukup, KS 1 keaktifan siswa kurang.

Indikator hasil belajar ranah kognitif nilai yang ditargetkan 75 dengan persentase $75 \%$. Penilaian dilakukan berdasarkan kemampuan siswa mampu mengerjakan soal yang diberikan. Pada ranah afektif nilai yang di tergetkan B dengan persentase $75 \%$, diamati pada saat proses pembelajaran yang meliputi keaktifan dan kerjasama siswa. Pada ranah psikomotorik nilai yang ditargetkan 75 dengan persentase $75 \%$, penilaian dilakukan pada saat siswa diskusi, mengerjakan tes, serta siswa mampu memahami materi yang diberikan.

\section{HASIL PENELITIAN DAN PEMBAHASAN}

Peningkatan keaktifan dan hasil belajar peserta didik, ditunjukkan oleh hasil nilai tes ketuntasan nilai belajar minimum peserta didik. Ketuntasan nilai belajar minimum merupakan ukuran dari kemampuan minimum peserta didik setelah mengikuti pembelajaran. Nilai 
minimum tersebut ditentukan oleh pihak penyelenggara pendidikan yaitu sekolah dan dinas terkait. Nilai batas minimal ketuntasan ditetapkan nilai 75, jika kurang dari nilai yang telah ditetapkan maka peserta didik harus remidi atau mengulang. Berikut ini hasil antar siklus yaitu :

\section{a) Pra Siklus}

Keaktifan siswa pada saat pelaksanaan observasi siswa dalam mengikuti proses pembelajaran kurang memperhatikan guru, selain itu pada saat guru menjelaskan materi siswa masih merasa malu untuk menanyakan materi yang belum jelas pada guru. Sehingga suasana menjadi membosankan karena tidak ada interaksi yang terjadi antara guru dengan siswa. Tingkat keaktifan siswa dapat dilihat pada gambar 1 .

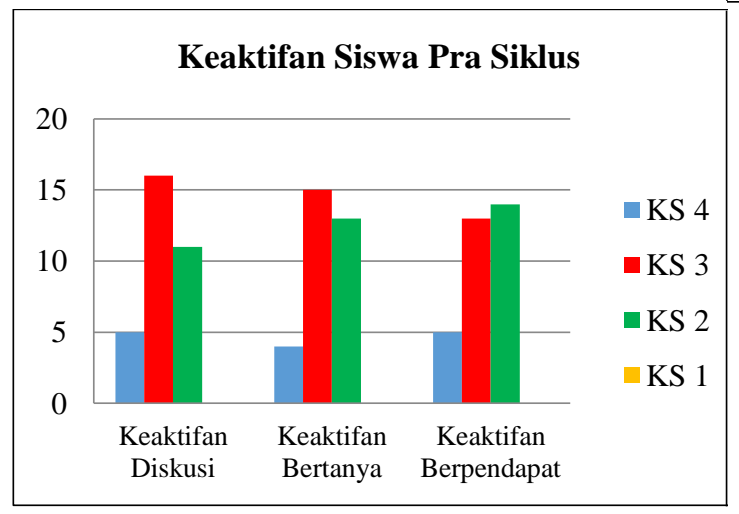

Gambar 1. Diagram Predikat Keaktifan Siswa Pra Siklus

Berikut diagram hasil belajar siswa pra siklus ranah kognitif, ranah afektif, dan ranah psikomotorik:

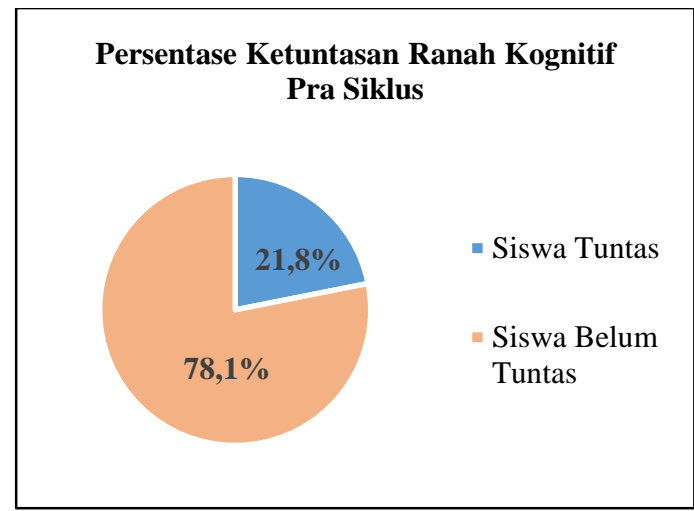

Gambar 2. Diagram persentase ketuntasan ranah kognitif pra siklus

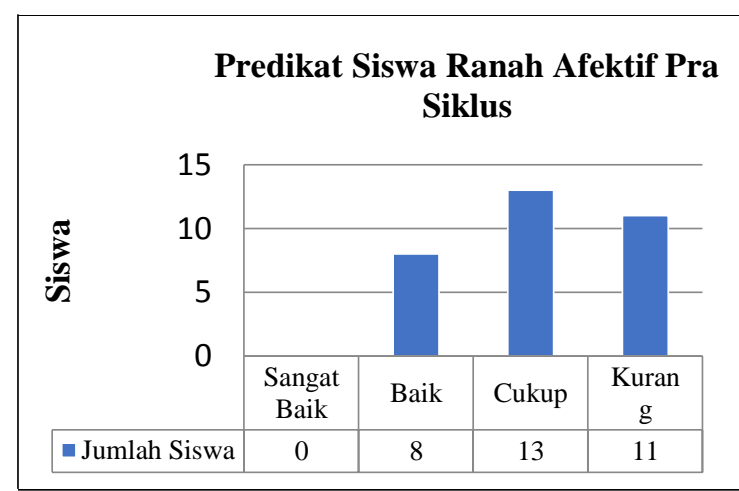

Gambar 3. Diagram Predikat Siswa Ranah Afektif Pra Siklus 


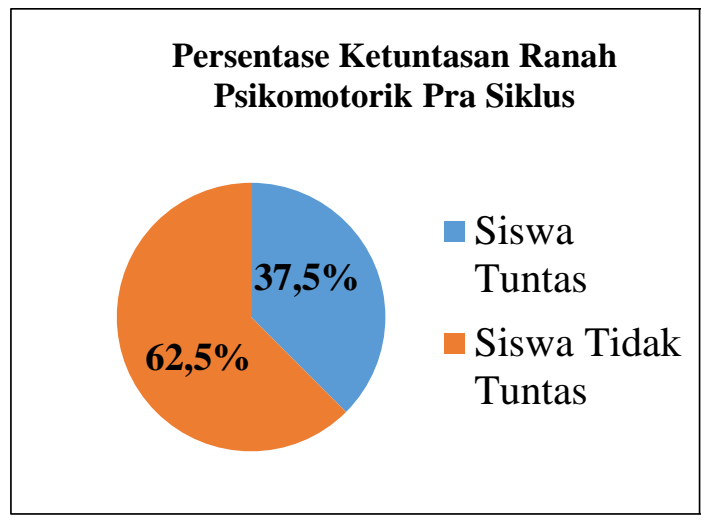

Gambar 4. Diagram Persentase Ketuntasan Ranah Psikomotorik Pra Siklus

Nilai diatas adalah nilai kompetensi siswa yang diperoleh dari pengolahan nilai kognitif. Siswa yang mendapat nilai $\geq 75$ sebanyak 7 orang siswa dengan persentase siswa tuntas sebesar $21,8 \%$. Sedangkan siswa yang mendapat nilai $<75$ sebanyak 25 orang siswa dengan persentase sebesar $78,1 \%$. Faktor yang mempengaruhi nilai belum mencapai KKM adalah pembelajaran yang monoton dikarenakan pembelajaran masih menggunakan metode ceramah, sehingga siswa mudah bosan dalam mengikuti pembelajaran.

Demikian pada ranah afektif pra siklus dengan skor target $75 \%$ dengan predikat Baik yaitu masih kurang dari yang sudah ditargetkan.
Pada pra siklus siswa yang mendapat predikat baik hanya 8 orang siswa. Hal ini dikarenakan kurang disiplin dan kurang aktifnya siswa dalam mengikuti pelajaran proses ini diamati selama pembelajaran berlangsung.

Aspek psikomotorik pada saat pra siklus belum sesuai yang ditargetkan yaitu sebesar $75 \%$, sedangkan pada pra siklus ketuntasan didapat 37,5\%, dikarenakan kurang aktifnya siswa pada saat mengikuti pelajaran selain itu kurangnya kesiapan siswa dalam menerima pelajaran terlihat masih banyak siswa yang meminjam alat belajar temannya pada saat proses belajar berlangsung.

\section{b) Siklus I}

Siklus pertama dilaksanakan pada hari Sabtu, 13 Februari 2016 dan Sabtu 27 Februari 2016 dengan alokasi waktu tiap pertemuan adalah $2 \times 45$ menit pada jam pelajaran ke 5-6 dengan jumlah keseluruhan 36 siswa. Data yang diperoleh pada siklus I yaitu : keaktifan siswa mengalami peningkatan dari pra siklus, dapat terlihat pada gambar 5 diagram keaktifan siswa berikut ini: 


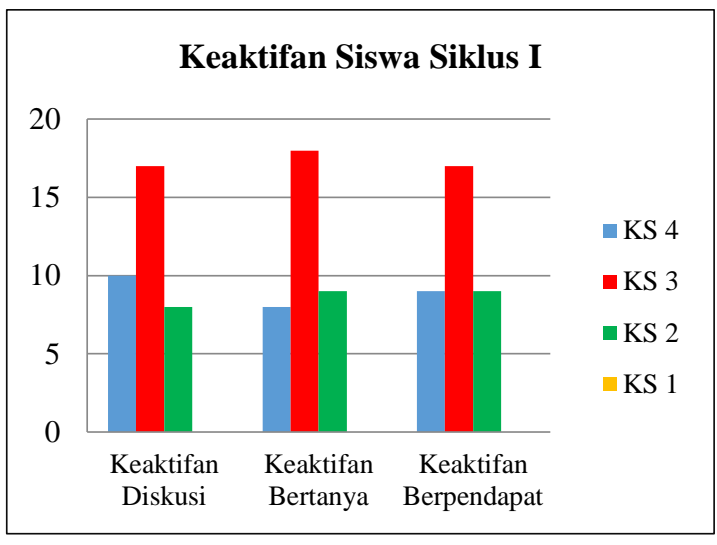

Gambar 5. Diagram Predikat Keaktifan Siswa Siklus I

Berikut diagram hasil belajar siswa siklus I ranah kognitif, ranah afektif, dan ranah psikomotorik:

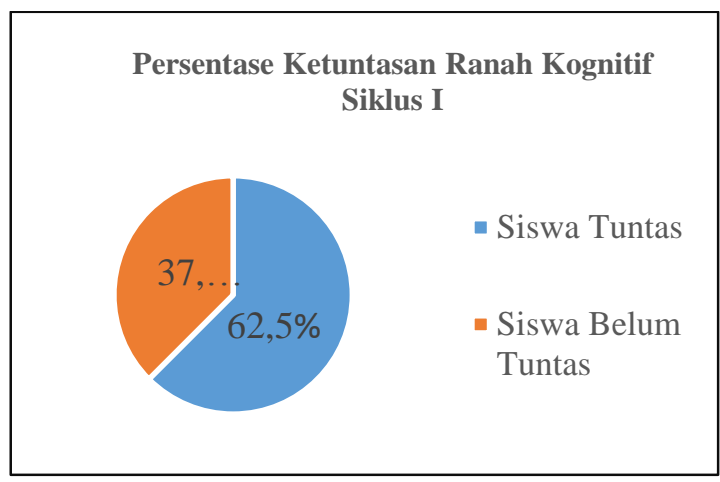

Gambar 6. Diagram Persentase Ketuntasan Ranah Kognitif Siklus I

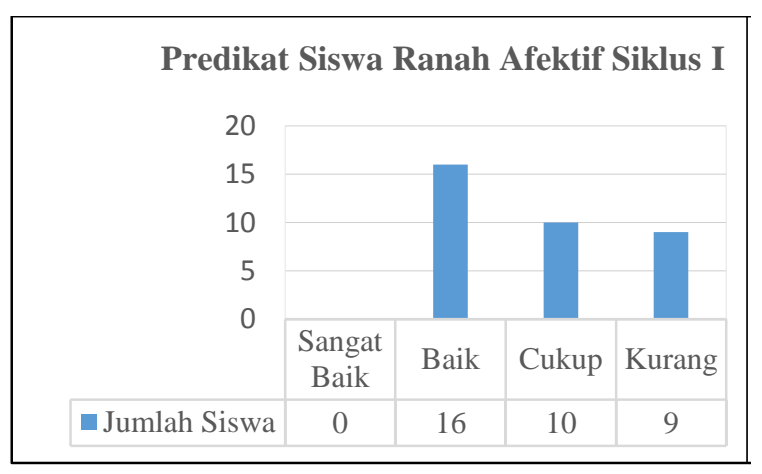

Gambar 7. Diagram Predikat Siswa Ranah Afektif Siklus I

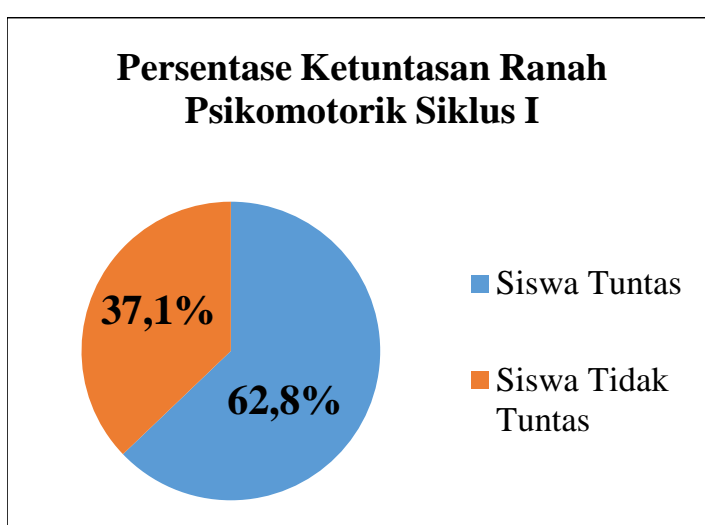

Gambar 8. Diagram Persentase Ketuntasan Ranah Psikomotorik Siklus I

Keaktifan siswa pada siklus I meningkat, terlihat pada aktifnya siswa dalam mengemukakan pendapat untuk mengerjakan soal yang telah diberikan oleh guru. Keaktifan diskusi juga meningkat karena mereka yang berdiskusi berpasangan merasa bertanggung jawab untuk menyelesaikan soal diskusi yang diberikan oleh guru, yang apabila mereka telah selesai maka mereka wajib men share jawaban mereka kepada anggota kelompok lain. Adapun bimbingan dari guru dalam melakukan diskusi kelompok, apabila mereka merasa belum paham maka mereka bertanya kepada guru, dalam 
diskusi kelompok guru bertugas memantau jalannya diskusi kelompok. Keaktifan siswa yang lain ditunjukkan pada saat kelompok lain mempresetasikan hasil diskusi kelompoknya, siswa aktif bertanya serta berpendapat berdasarkan apa yang telah di presentasikan kelompok lain yang dianggap mereka belum jelas.

Pada siklus I, hasil belajar siswa mengalami peningkatan dibandingkan dengan siklus sebelumnya. Peningkatan yang sedikit ini dikarenakan keadaan siswa yang belum terbiasa dengan menggunakan model pembelajaran padu padan. Kondisi kelas yang monoton membuat siswa menjadi pasif dan kurang bersemangat dalam mengikuti pembelajaran. Terlebih kondisi jam pelajaran yang berlangsung di siang hari pada jam ke 5-6 membuat siswa mengantuk dan tidak bersemangat. Ranah kognitif pada siklus I, ketuntasan belajar pada tes kognitif mencapai $62,5 \%$ dan ketidak tuntasan hasil kognitif sebesar 37,5\%. Faktor yang mempengaruhi nilai belum mencapai target adalah suasana kelas yang kurang kondusif. Pada siklus I siswa yang mendapat predikat baik 16 orang siswa. Hal ini dikarenakan keaktifan siswa sudah mulai terlihat pada saat pembelajaran yaitu bertanya dan berpendapat, kerjasama siswa dalam berdiskusi kelompok juga sudah mulai aktif, walaupun masih ada beberapa anggota kelompok yang pasif, serta kedisiplinan dan tanggung jawab siswa sudah mulai baik didalam mengikuti pembelajaran, akan tetapi masih terlihat beberapa anak yang belum bertanggung jawab terhadap tugasnya. Aspek psikomotorik pada saat siklus I belum sesuai yang ditargetkan yaitu sebesar 75\%, sedangkan pada siklus I ketuntasan didapat $62,8 \%$. Hal ini dikarenakan kurang aktifnya siswa pada saat mengikuti pelajaran, dan juga kurangnya kesiapan siswa dalam menerima pelajaran, siswa masih sibuk meminjam alat tulis kepada temannya, terlihat kemampuan siswa menjelaskan jawaban di depan temannya masih kurang, serta kurang aktifnya siswa dalam mengemukakan 
pendapat pada saat proses pembelajaran dan juga pada saat siswa melakukan diskusi kelompok.

\section{c) Siklus II}

Penelitian tindakan kelas siklus II ini dilaksanakan pada hari Sabtu, 27 Februari 2016 dan pada hari sabtu, 5 Maret 2016. Pada keaktifan siswa mengalami peningkatan dari pra siklus ke siklus I kemudian menuju siklus II. Kenaikan tersebut dapat terlihat pada diagram keaktifan siswa dibawah ini:

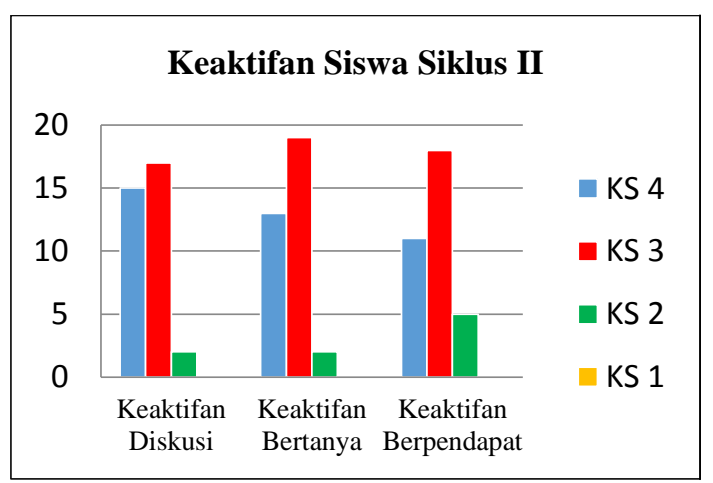

Gambar 9. Diagram predikat keaktifan siswa siklus II

Berikut diagram hasil belajar siswa siklus I ranah kognitif, ranah afektif, dan ranah psikomotorik:

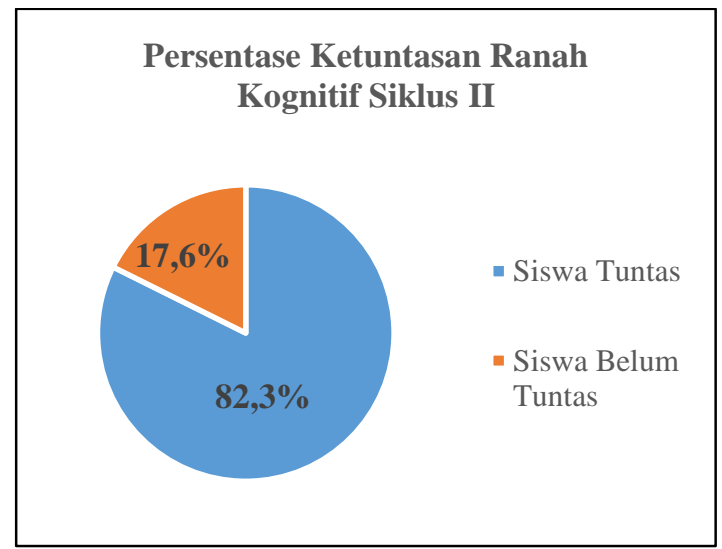

Gambar 10. Diagram Persentase Ketuntasan Ranah Kognitif Siklus II

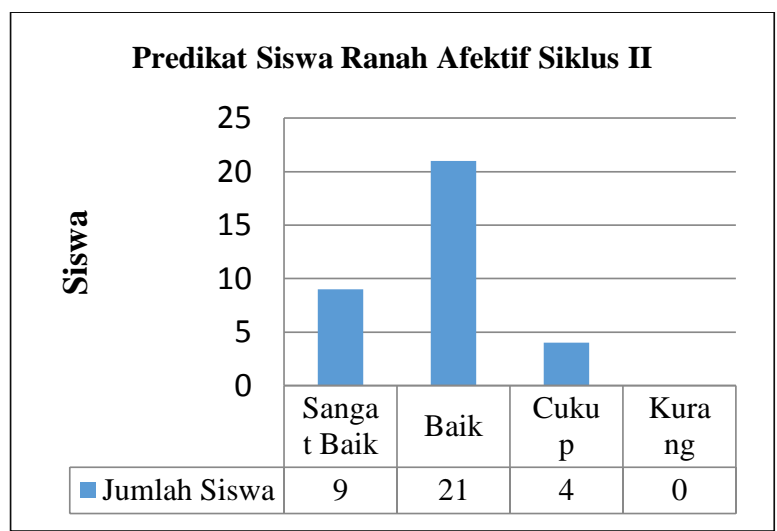

Gambar 11. Diagram Predikat Ranah Afektif Siklus II

Persentase Ketuntasan Ranah Psikomotorik Siklus II

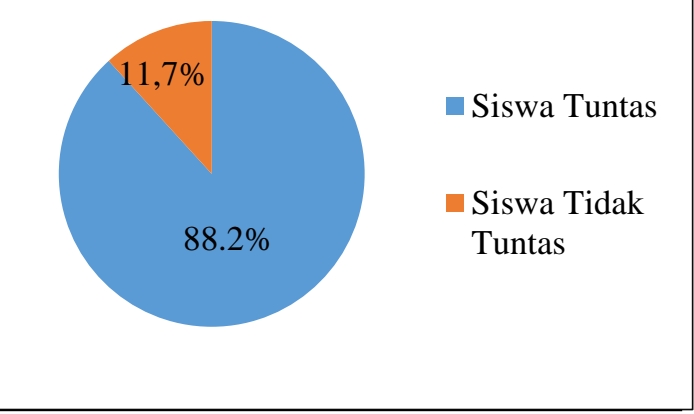

Gambar 12. Diagram

Persentase Ketuntasan Ranah

Psikomotorik Siklus II 
Keaktifan siswa dalam pelaksanaan siklus II mengalami peningkatan, pada siklus II pelaksanaan diskusi dibagi menjadi 6 kelompok setiap kelompok terdiri dari 6 anggota dari sini keaktifan siswa yang dicapai mengalami peningkatan, hal ini dikarenakan dalam setiap kelompok memiliki 2 top leader yang mampu mempengaruhi anggota lain untuk ikut aktif didalam proses pembelajaran.

Hasil belajar siswa pada siklus II mengalami peningkatan, ketuntasan belajar pada tes kognitif mencapai $82,3 \%$ dan ketidak tuntasan hasil kognitif sebesar $17,6 \%$. Pada siklus II ini terlihat adanya peningkatan ketuntasan karena nilai yang didapat siswa telah mencapai KKM, sehingga untuk siklus II ini sudah mencapai target keberhasilan untuk ranah kognitif. Hal ini terjadi karena siswa sudah mulai terbiasa dengan model pembelajaran padu padan, karena pembelajaran mudah dipahami. Pada ranah afektif siswa pada siklus II dengan skor target $75 \%$ dengan predikat Baik yaitu meningkat ditambah lagi yang berpredikat Sangat Baik sudah mulai terlihat. Pada siklus II siswa yang mendapat predikat baik 21 orang siswa. Hal ini dikarenakan keaktifan siswa sudah mulai terlihat pada saat pembelajaran yaitu kerjasama siswa dalam berdiskusi kelompok, kedisiplinan siswa dalam menerima pelajaran mulai tampak, seperti siswa memperhatikan guru saat menjelaskan materi, juga sudah mulai aktif dalam bertanya dan berpendapat mengenai materi yang dianggap belum jelas. Serta tanggung jawab siswa mengalami peningkatan yaitu terhadap tugas-tugas yang harus diselesaikan. Selanjutnya pada ranah psikomotorik pada siklus II telah sesuai dengan yang ditargetkan yaitu sebesar $75 \%$. Pada siklus II ini ranah psikomotorik mengalami peningkatan yaitu siswa tuntas sebesar 88,2\% sedangkan siswa tidak tundas sebesar $11,7 \%$. Terjadinya peningkatan yaitu karena siswa telah mampu menjelaskan jawaban di depan teman sekelasnya, siswa lebih aktif dalam menanyakan materi yang dianggap belum paham, aktifnya siswa dalam mengemukakan 
pendapat pada saat proses pembelajaran dan juga pada saat siswa melakukan diskusi kelompok, kemudian juga terlihat pada kesiapan siswa dalam mempersiapkan alat belajarnya sebelum pembelajaran dimulai.

Hasil penelitian dengan menerapkan model pembelajaran padu padan antara Student Team Achievement Division (STAD), Think Pair Share (TPS), dan Problem Based Learning (PBL) pada kelas X TGB-B SMK X terbukti dapat meningkatkan keaktifan siswa dan hasil belajar siswa. Semua aspek hasil belajar seperti ranah kognitif, ranah afektif dan ranah psikomotorik mengalami peningkatan nilai ketuntasannya. Hal ini sejalan dengan hasil penelitian yang dilakukan oleh beberapa peneliti sebelumnya. Aci Primartadi (2011) dalam hasil penelitiannya terlihat STAD dipadukan dengan PBL terhadap potensi akademik siswa dan pengaruhnya terhadap pencapaian hasil belajar yaitu dapat disimpulkan secara keseluruhan hasil belajar antara siswa yang diajar dengan model pembelajaran STAD dan PBL tidak terdapat perbedaan. Dari hasil ini bahwa kedua metode tersebut secara umum mempunyai pengaruh yang sama terhadap peningkatan hasil belajar siswa. Kemudian Hari Hardiyan (2014) dalam hasil penelitiannya model pembelajaran TPS dipadukan dengan PBL dalam meningkatkan hasil belajar siswa yaitu dapat disimpulkan penggunaan kolaborasi model TPS dan PBL sudah efektif dimana ada kenaikan yang cukup baik pada presentase ketuntasan pada siklus I 35\% meningkat menjadi $88 \%$ pada siklus II.

\section{KESIMPULAN}

Berdasarkan hasil penelitian dan pembahasan penelitian tindakan kelas ini dapat ditarik kesimpulan sebagai berikut: 1) model pembelajaran padu padan dapat meningkatkan keaktifan siswa pada mata pelajaran Bahan Bangunan. 2) model pembelajaran padu padan dapat meningkatkan hasil belajar siswa pada mata pelajaran Bahan Bangunan, baik 
ranah kognitif, ranah afektif ataupun ranah psikomotorik.

\section{SARAN}

Berdasarkan hasil penelitian tindakan kelas yang telah dilaksanakan, maka ada beberapa saran yang dikemukakan yaitu:

Mengingat pelaksanaan penelitian hanya berjalan 2 siklus, maka guru mata pelajaran Bahan Bangunan SMK $\mathrm{X}$ diharapkan mampu melanjutkan menerapkan model pembelajaran Padu Padan agar mendapat temuan baru yang lebih signifikan.

Dalam penerapan penelitian ini yakni kegiatan pembelajaran membutuhkan waktu yang cukup dan suasana kelas yang mendukung, dengan demikian diharapkan adanya partisipasi antara guru dan siswa yang saling bekerjasama untuk kelancaran penelitian.

Mengingat pelaksanaan penelitian ini hanya menggunakan 3 siswa sebagai sampel wawancara, diharapkan dapat dilanjutkan oleh penelitian selanjutnya dengan menggunakan angket atau wawancara lebih dari 3 siswa agar untuk mendapatkan hasil yang lebih akurat dalam meningkatkan hasil belajar dan keaktifan siswa sehingga tujuan pembelajaran tercapai.

Pada saat penelitian masih adanya siswa yang kurang tanggap terhadap model belajar yang digunakan, sebaiknya pada penelitian selanjutnya kegiatan belajar yang akan berlangsung lebih dimodifikasi agar mencapai tujuan pembelajaran yang baik.

\section{DAFTAR PUSTAKA}

Adnan, (2013). Penerapan Model Pembelajaran Kooperatif Tipe Think Pair Share (TPS) Untuk Meningkatkan Keaktifan Dan Prestasi Belajar Siswa Kelas $X$ Otomotif 1 SMK PGRI 1 Surakarta Pada Mata Diklat Otomotif Dasar Tahyn Pelajaran 2012/2013. Skripsi. Surakarta: FKIP Universitas Sebelas Maret.

Agung Leo, dan Suryani Nunuk. (2012). Strategi Belajar Mengajar. Yogyakarta: Ombak.

$\begin{array}{cc}\text { Conietta Vyonella Zeyn. } & \text { (2015). } \\ \text { Penerapan } & \text { Model } \\ \text { Pembelajaran } & \text { ARCS }\end{array}$


(Attention, Relevance, Confidence, Satisfaction) dan Alat Peraga Komponen Bangunan Untuk Meningkatkan Hasil Belajar Siswa Kelas X TGB A SMK Negeri 2 Sukoharjo. Skripsi. Surakarta: FKIP Universitas Sebelas Maret.

Dewi, Amelia. (2015). Penerapan Model Pembelajaran Think Pair Share (Tps) Dipadukan Dengan Problem Based Learning (Pbl) Dalam Meningkatkan Kemampuan Berpikir Kritis Siswa SMA Negeri 1 Comal. Jurnal. Universitas Negeri Semarang. Diunduh dari http://lib.unnes.ac.id/22889/1 /4201411021.pdf Pada 13 Januari 2016, Pukul 10:10.

\begin{tabular}{|c|c|}
\hline \multirow{11}{*}{ Direktorat } & $\begin{array}{l}\text { Pembinaan } \\
\text { Menengah }\end{array}$ \\
\hline & Kementrian Pendidikan dan \\
\hline & Kebudayaan \\
\hline & Jenderal Pendidikan Dasar \\
\hline & Dan Menengah. (2015). \\
\hline & Panduan Penilaian pada \\
\hline & Menengah \\
\hline & Kejuruan. \\
\hline & Kementrian \\
\hline & $\begin{array}{l}\text { Nasional. diunduh dari } \\
\text { http://psmk.kemdikbud.go.i }\end{array}$ \\
\hline & $\frac{\mathrm{d} /}{2016 .}$ pada tanggal 13 juni \\
\hline
\end{tabular}

Hardiyan, Hari. (2014). Jurnal Penerapan Model Pembelajaran Gabungan
Antara Problem Based Learning (PBL) Dan Think Pair Share (TPS) Dalam Rangka Meningkatkan Hasil Belajar Mata Pelajaran Kelistrikan Otomotif Siswa Kelas XI Jurusan Teknik Kendaraan Ringan (TKR) Di SMK Negeri 2 Yogyakarta. Diunduh dari http://eprints.uny.ac.id/203 44/1/Hary\%20Hardiyan $\% 2$ 008504241018.pdf

Pada 13 Januari 2016, Pukul 10:10.

Heydon, (2007). Multi Methods In Enginering Learning Process To Develop High Order Thinking Skill Of Pre Service Vocational Engineering Teacher.

Huda, Miftahul. (2013). Model-Model Pengajaran dan Pembelajaran Yogyakarta: Pustaka Pelajar.

Huda, Miftahul. (2015). Cooperative Learning. Yogyakarta: Pustaka Pelajar.

Husen, (1997). Pendekatan Multipe Dalam Pembelajaran Menulis. Diunduh 17 Mei 2016 dari https://try599.wordpress.com/ 2014/08/16/pendekatanmultiple-inteligencess-dalampembelajaran-menulissuratkorespondensi/ 
Lukas, (2016). Penerapan Metode Pembelajaran Snowball Throwing Blended Dengan Student Facilitator And Explaining Untuk Meningkatkan Prestasi Belajar Dan Keaktifan Siswa Pada Mata Pelajaran Ilmu Bahan Bangunan Gedung Kelas X TGB SMK Negeri 4 Sukoharjo Tahun Ajaran 2015/2016. Skripsi. Surakarta: FKIP Universitas Sebelas Maret.

Natawijaya, Rochman. (2005). Bunga Rampai Keberhasilan Guru dalam Pembelajaran (SMA, SMK, dan SLB). Jakarta: Depdiknas.

Nurido, (2015). PenerapanModel Pembelajaran Kooperatif Tipe Learning Together Untuk Meningkatkan Keaktifan Dan Hasil Belajar Siswa Kelas X Mata Pelajaran Dasar Kompetensi Kejuruan Di SMK Bhineka Karya Surakarta Tahyn Pelajaran 2014/2015. Skripsi. Surakarta: FKIP Universitas Sebelas Maret.

Primartadi, Aci. (2011). Pengaruh Metode Student Team Achievement Division (STAD) Dan Problem Based Learning Terhadap Hasil Belajar Ditinjau Dari Potensi Akademik Siswa SMK Otomotif. Jurnal.
Yogyakarta: Universitas Yogyakarta.

Salirawati, Das. (2011). Teknik Analisis Data Dalam PTK. Jurnal. Universitas Yogyakarta. Diunduh dari http://staff.uny.ac.id/.../Tekni $\mathrm{k} \% 20$ Analisis\%20data\%20P TK\%20Mlati_0.doc Pada 16 Juni 2016

Suprijono, Agus. (2013). Cooperative Learning, Teori \& Aplikasi Paikem. Yogyakarta: Pustaka Pelajar.

Sutopo, H.B. (2006). Metodologi Penelitian Kualitatif (dasar teori dan terapannya dalam penelitian). Surakarta: Universitas Sebelas Maret.

Tim Penyusun Pedoman Skripsi FKIP UNS. (2016). Pedoman Penulisan Skripssi Fakultas Keguruan Dan Ilmu Pendidikan. Surakarta: UNS Press.

Wiriaatmadja Rochiati. (2012). Metode Penelitian Tindakan Kelas. Bandung: PT. Remaja Rosdakarya. 